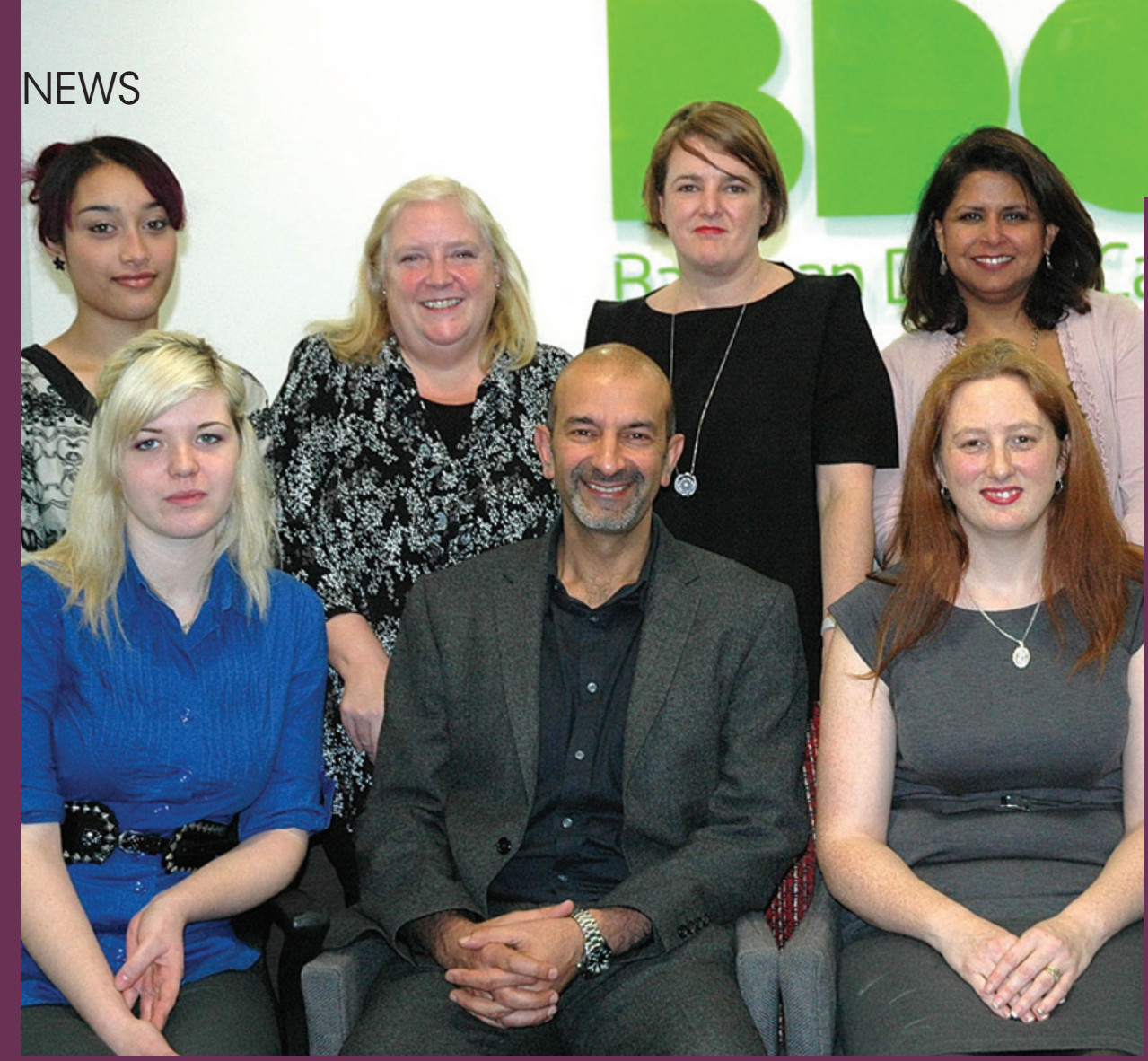

Some of the new recruits with dental practice staff, Neil Sikka (front row) and Clare Coombe of Skills Match (front row, right)

\section{POSITION YOUR PRACTICE AT THE FOREFRONT OF TECHNOLOGY}

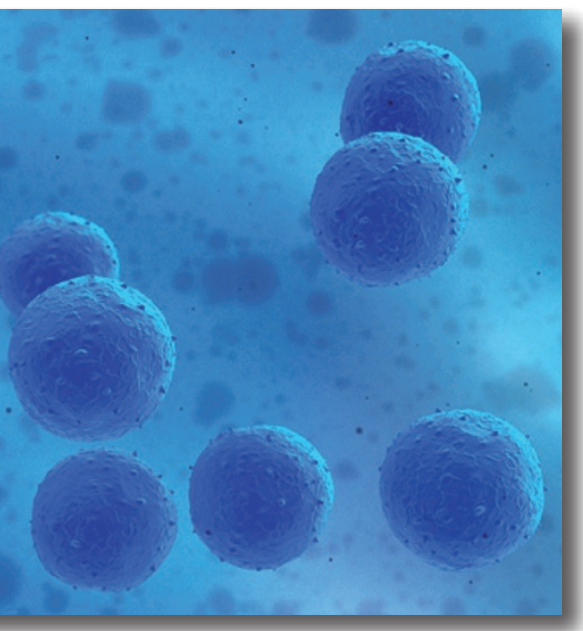

Precious Cells International (PCI) have opened their central stem cell processing and storage facility at Brunel Science Park, near Uxbridge, London.

PCI is the only family stem cell bank in the world to offer collection, processing and long term storage of stem cells from five different sources in the body: umbilical cord blood and tissue, bone marrow, adipose tissue and teeth.

Stem cells from teeth are found in pulp (DPSCs) and exfoliated deciduous teeth (SHED). SHED cells have the unique advantage of being retrievable from naturally exfoliated teeth which can be considered a disposable source of postnatal human tissue. Deciduous teeth, healthy wisdom teeth and permanent teeth extracted for orthodontic purposes all contain stem cells that have the ability to develop into many different types of tissue (skin, nerve, muscle, fat, cartilage and tendon) and can potentially be used to replace diseased and damaged tissues in the body without rejection.

Teeth are by far the most natural, non-invasive source of stem cells. There are no medical interventions required and no religious or ethical objections to overcome.

In the near future it is predicted that dentistry will move from restorative to regenerative, as dental stem cells show their capability to regrow teeth, jawbone, and muscle tissue.

PCI now offers dentists the opportunity to become affiliate healthcare professionals in order to offer their patients what could be a life-saving opportunity to preserve precious stem cells and to position the dental practice at the forefront of modern health technology.

Patient educational leaflets explain the opportunity for storing stem cells from teeth and the potential health benefit for the patient or patient's family. Further website support is also available for patients.

Visit www.precious-cells.com or telephone 08454755221 for further information.

\section{URBAN YOUTHS RECRUITED FOR DENTAL NURSING}

Neil Sikka of Barbican Dental Care in London has created the iNSkills initiative which will provide disaffected youth in the Tower Hamlets area with the opportunity to achieve an NVQ Level 3 qualification in dental nursing.

Working in conjunction with the local council, college and other practices in the City of London and Canary Wharf, the initiative will provide training and real job prospects for a vulnerable group.

'Within the Square Mile there are some of the most successful businesses and the richest people. But just outside is Tower Hamlets, the poorest borough in the UK', said Dr Sikka. 'We wanted to create a scheme where we could offer people the chance of training, work and, more importantly, career development.'

The pilot scheme, launched in February 2012, has sourced eight trainees from the borough of Tower Hamlets. Tower Hamlet Council's Skillsmatch - an outreach team with established links in the community sourced the candidates and will mentor the trainees throughout the duration of the course. Tower Hamlets College will provide the training on a dayrelease basis and students will gain work experience and valuable on-thejob training.

The initiative includes an 'earn as you learn' element, where students will be paid for their working and college time.

Dr Sikka now plans to roll out the programme to other practices within and adjacent to Tower Hamlets. Any interested practice owners can contact Dionne Marsh by emailing: dee.m@ barbicandentalcare.com.

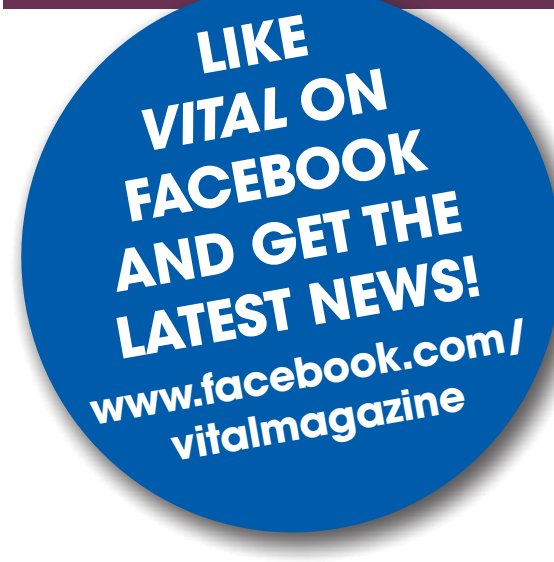

